\title{
Hepatoprotection and Phytochemistry of the Vietnamese Herbs Cleome chelidonii and Cleome viscosa Stems
}

\author{
Nhat Minh Phan $\mathbb{D},{ }^{1,2}$ Thi Hong Tuoi Do ${ }^{(D)}{ }^{3}$ Le Thanh Tuyen Nguyen $\left(\mathbb{D},{ }^{4}\right.$ \\ Trong Tuan Nguyen, ${ }^{5}$ Quoc Luan Ngo ${ }^{D},{ }^{5}$ Trong Duc Tran $\mathbb{D}^{6},{ }^{6}$ Quan Hien Nguyen, ${ }^{7}$ \\ Bui Linh Chi Huynh, ${ }^{8}$ Diep Xuan Ky Nguyen $\mathbb{D}^{2},{ }^{2}$ Trong Dat Bui $\mathbb{D}^{2}$, Dinh Tri Mai $\mathbb{D},{ }^{1,9}$ \\ and Tan Phat Nguyen (iD) 1,9 \\ ${ }^{1}$ Faculty of Chemistry, Graduate University of Science and Technology, Vietnam Academy of Science and Technology, \\ 18 Hoang Quoc Viet Cau Giay, Hanoi, Vietnam \\ ${ }^{2}$ Natural Products Laboratory, Institute of Chemical Technology, Vietnam Academy of Science and Technology, \\ 01 A Thanh Loc 29 Thanh Loc District 12, Ho Chi Minh City, Vietnam \\ ${ }^{3}$ Faculty of Pharmacy, University of Medicine and Pharmacy, 41 Dinh Tien Hoang District 1, Ho Chi Minh City, Vietnam \\ ${ }^{4}$ Saigon Pharmaceutical Sciences \& Technologies Center, University of Medicine and Pharmacy, 41 Dinh Tien Hoang District 1, \\ Ho Chi Minh City, Vietnam \\ ${ }^{5}$ Can Tho University, 3/2 Street Ninh Kieu District, Can Tho City, Vietnam \\ ${ }^{6}$ University of the Sunshine Coast, 90 Sippy Downs Drive, Sippy Downs 4556, Queensland, Australia \\ ${ }^{7}$ Ho Chi Minh City Institute of Physics, Vietnam Academy of Science and Technology, 01 Mac Dinh Chi District 1, \\ Ho Chi Minh City, Vietnam \\ ${ }^{8}$ Department of Science, Dong Nai University, Bien Hoa City, Dong Nai, Vietnam \\ ${ }^{9}$ Bioactive Compounds Laboratory, Institute of Chemical Technology, Vietnam Academy of Science and Technology, \\ 01A Thanh Loc 29 Thanh Loc District 12, Ho Chi Minh City, Vietnam
}

Correspondence should be addressed to Tan Phat Nguyen; phat_nguyentan88@yahoo.com

Received 12 January 2021; Revised 7 April 2021; Accepted 10 April 2021; Published 19 April 2021

Academic Editor: José Morillo

Copyright (c) 2021 Nhat Minh Phan et al. This is an open access article distributed under the Creative Commons Attribution License, which permits unrestricted use, distribution, and reproduction in any medium, provided the original work is properly cited.

The study aims to determine the hepatoprotective effect of $n$-hexane, ethyl acetate, and methanol extracts of the leaves and stems of two Cleome species against carbon tetrachloride- $\left(\mathrm{CCl}_{4^{-}}\right)$induced liver toxicity both in vitro using human hepatoma (HepG2) cells and in vivo in rats as well as the hepatoprotective property of all isolated compounds on HepG2. After $72 \mathrm{~h}$ of treatment, at the concentrations of 25,50 , and $100 \mu \mathrm{g} / \mathrm{mL}$, the methanol of C. chelidonii stems (CCSM) ranged from $18.6 \%$ to $20.8 \%$, whereas the methanol of C. chelidonii stems (CVSM) increased from $12.3 \%$ to $17.2 \%$ cell viability. The results show that CCSM and CVSM significantly expressed in vitro hepaprotective activity on HepG2. Therefore, the animals were daily treated with these extracts at the doses of 15,30 , and $45 \mathrm{mg} / \mathrm{kg}$ body weight for 5 days, and $\mathrm{CCl}_{4}$ was injected $(2 \mathrm{ml} / \mathrm{kg}$ body weight, i.p.) on the $2 \mathrm{nd}$ and $3 \mathrm{rd}$ days. Levels of aspartate aminotransferase (ALT) and alanine aminotransferase (AST) in the blood were measured and compared to the silymarin control. The treatments with CCSM and CVSM $(30$, and $45 \mathrm{mg} / \mathrm{kg}$ ) possessed significant hepatoprotection and were comparable with the activity of silymarin. Further, phytochemical studies of these ones were conducted and led to the identification of eight flavonoids: visconoside A (1), visconoside B (2), quercetin 3-O- $\beta$-D-glucopyranoside 7-O- $\alpha$-L-rhamnopyranoside (3), kaempferol 3-O- $\beta$-D-glucopyranoside 7-O- $\alpha$-L-rhamnopyranoside (4), cleomeside A (5), cleomeside B (6), cleomeside $\mathrm{C}(7)$, and quercetin-3-O-[ $\beta$-D-glucopyranosyl- $(1 \longrightarrow 2)]-\alpha$-L-rhamnopyranoside 7 - $O$ - $\alpha$-L-rhamnopyranoside $(8)$. Two major flavonoids (1 and 4) displayed significant hepatoprotective property (at the concentration of $100 \mu \mathrm{M}$, the prevention percentage values were $66.5 \%$ and $74.2 \%$, respectively, compared to the quercetin control, with value of $80.3 \%$ ). 


\section{Introduction}

The genus Cleome belonging to the Cleomaceae family comprises about 170 species[1]. Five species were found in Vietnam [2]. In the traditional Vietnamese medicine, C. chelidonii is used for treatment of fever, flu, headache, cough, snake bite, and nephritis, whereas C. viscosa is used to treat diarrhea, fever, inflammation, liver diseases, bronchitis, skin diseases, and malarial fever [2]. Pharmacological investigations proved that $C$. chelidonii possessed antipyretic [3], antihyperglycemic [4], and anthelmintic [5] properties, while C. viscosa expressed anticonvulsant [6], antitumor [7], cytotoxic [8-12], antiangiogenic [12], antimalarial [13], larvicidal [14], antiallergic, diuretic [15], analgesic, antipyretic [16], $\alpha$-glucosidase, and $\alpha$-amylase inhibitory [17] activities. Additionally, both species exhibited antimicrobial [9-21], antinociceptive [3, 10, 22, 23], antiinflammatory $[3,21,23,24]$, and antioxidant activities $[5,8,9,12,14,25-27]$.

In vivo study on rats against $\mathrm{CCl}_{4}$-induced liver injury indicated that hydroalcohol, methanol, ethyl acetate, and hexane extracts of $C$. chelidonii root revealed hepatoprotective activity [28]. Another study on rats against paracetamol- and ethanol-induced liver toxicity also confirmed that a methanol extract of $C$. chelidonii's whole plant displayed hepatoprotective property [24]. In vivo study on ethanol extract of $C$. viscosa's whole plant against $\mathrm{CCl}_{4}$-induced hepatotoxicity [29], as well as methanol extract against streptozotocin- (STZ-) induced diabetic rats [30], C. viscosa leaves against thioacetamide-induced hepatotoxicity $[31,32]$, and C. viscosa seeds against paracetamol-induced hepatotoxicity $[33,34]$ also showed that $C$. viscosa possessed a hepatoprotective effect on rat models.

So far, there has been no report on the hepatoprotection and phytochemical constituents of the C. chelidonii and C. viscosa stems. Continuing our study on bioactive composition of traditional Vietnamese medicines [35] and the Cleome genus [36-39], this paper detailed the evaluation of the hepatoprotective effect of different extracts ( $n$-hexane, ethyl acetate (EtOAc), and methanol ( $\mathrm{MeOH}$ ) extracts) from the stems of two Cleome species against $\mathrm{CCl}_{4}$-induced liver intoxication in both in vitro and in vivo assays. All compounds isolated from the most active extracts were also measured for the hepatoprotective activity using in vitro assay.

\section{Materials and Methods}

2.1. Plant Materials. C. chelidonii and C. viscosa stems were collected in Ben Cat, Binh Duong province, Vietnam, in May 2015 and certificated by Professor Vo Van Chi. The voucher specimens (No. VH/MINH-1012 and No. VH/MINH-0515, respectively) were deposited in the Institute of Chemical Technology, Vietnam Academy of Science and Technology.

2.2. Extraction. Dried stems powders of C. chelidonii ( $8 \mathrm{~kg})$ and C. viscosa $(7 \mathrm{~kg})$ were extracted with $96 \% \mathrm{EtOH}$ for three times $(3 \times 30 \mathrm{~L}$, total amount $90 \mathrm{~L})$ at room temperature. The supernatants were filtered, and the solvents were removed under vacuum to obtain crude extracts CCS (970 g) and CVS (770 g), respectively. Those extracts were subjected to solid-phase separation and successively fractionated into $n$ hexane, EtOAc, and $\mathrm{MeOH}$ extracts, respectively, to afford six extracts: CCSH (155 g), CCSE (355 g), CCSM (420 g), CVSH (130 g), CVSE (310 g), and CVSM (330 g). Similar protocols were used for powdered leaves of $C$. chelidonii $(5 \mathrm{~kg})$ and $C$. viscosa $(7.5 \mathrm{~kg})$, resulting in six extracts: CCLH (120 g), CCLE (228 g), CCLM (170 g), CVLH (150 g), CVLE (260 g), and CVLM (400 g). All extracts were stored at $4^{\circ} \mathrm{C}$ for further studies.

2.3. Chemicals and Reagents. Eagle's Minimum Essential Medium (EMEM), fetal calf serum (FCS), and trypsinEDTA were purchased from Gibco, USA; L-glutamine, penicillin, streptomycin, phosphate buffer, 3-(4, 5-dimethylthiazol-2-yl)-2,5-diphenyltetrazolium bromide (MTT), doxorubicin, and carbon tetrachloride $\left(\mathrm{CCl}_{4}\right)$ were from Sigma-Aldrich, USA; dimethyl sulfoxide (DMSO) and isopropanol were from Merck, Germany. All chemicals met cell culture standards.

2.4. Cell Culture. HepG2 cells (the American Type Culture Collection, Manassas, Rockville) were seeded and cultured in EMEM containing 10\% FCS (v/v), 2 mM L-glutamine, 100 $\mathrm{IU} / \mathrm{mL}$ penicillin, and $100 \mu \mathrm{g} / \mathrm{mL}$ streptomycin at $5 \% \mathrm{CO}_{2}$ at $37^{\circ} \mathrm{C}$ to attain confluency.

2.5. Animals. Swiss albino mice weighing 26-30g were purchased from Pasteur Institute in Ho Chi Minh City, Vietnam Ministry of Health. The mice were housed in standard cages $(48 \mathrm{~cm} \times 35 \mathrm{~cm} \times 22 \mathrm{~cm})$ at room temperature and provided with pelleted food and water.

\subsection{Evaluation of the In Vitro and In Vivo Hepatoprotective Activity}

2.6.1. Cell Viability. HepG2 cells were harvested and seeded in 96 -well plates at $4.0 \times 10$ cells $/ \mathrm{cm}^{2}$. Then, cells were treated with EMEM containing $2 \mathrm{mM} \mathrm{CCl}_{4}$ and compounds $1-8$ alone or combined at different concentrations. Cell viability was measured as mitochondrial succinate dehydrogenase activity, a marker of viable cells using MTT test. Doxorubicin was used as positive control for cytotoxicity. The assay was performed using the MTT test, as previously described $[17,18]$. Doxorubicin was used as a positive control for cytotoxicity.

For the cytotoxicity, the percentage of control (\%) was calculated $=\mathrm{OD}_{570}$ sample $/ \mathrm{OD}_{570}$ control $\times 100 \%$ measured at the different concentrations $(25,50$, and $100 \mu \mathrm{g} / \mathrm{mL})$ by MTT assay.

2.6.2. Study on Hepatic Protective Effect in Mice Acute Liver Injury Induced by $\mathrm{CCl}_{4}$. Mice were divided into six groups with six animals in each group. 
Group I (normal control) received distilled water with $0.3 \%$ sodium carboxymethylcellulose (CMC-Na) $(1 \mathrm{~mL} / \mathrm{kg}$ body weight, p.o.) for 5 days and olive oil $(1 \mathrm{~mL} / \mathrm{kg}$ body weight, i.p.) on days 2 and 3.

Group II $\left(\mathrm{CCl}_{4}\right.$-intoxicated) received $0.3 \% \mathrm{CMC}-\mathrm{Na}$ ( $1 \mathrm{~mL} / \mathrm{kg}$ body weight, p.o.) for 5 days and $\mathrm{CCl}_{4}$-olive oil (1:1, $2 \mathrm{~mL} / \mathrm{kg}$ body weight, i.p.) on days 2 and 3 .

Group III (positive group) was treated daily with the positive silymarin drug (100 mg/kg body weight, p.o.) for 5 days and $\mathrm{CCl}_{4}$-olive oil $(1: 1,2 \mathrm{~mL} / \mathrm{kg}$ body weight, i.p. $)$ on days 2 and 3, 30 min after silymarin administration.

Test groups (IV-VI) were administered orally with 100,200 , and $400 \mathrm{mg} / \mathrm{kg}$ TFs, respectively, for 5 days. The three test groups received $\mathrm{CCl}_{4}$-olive oil $(1: 1,2 \mathrm{~mL} / \mathrm{kg}$, i.p.) on days 2 and 3, 30 min after TFs administration.

The mice were killed after the $24 \mathrm{~h}$ treatment. Blood was collected via heart puncture and serum was separated for examination of various biochemical parameters. The liver was carefully dissected and cleaned of extraneous tissue. A portion of the liver tissue was immediately transferred into $10 \%$ formalin for histopathologic investigation. Levels of biochemical parameters ALT and AST were measured and compared with silymarin control [15].

2.7. General Experimental Procedures for Isolation and Structural Identification. Column chromatography was carried out using Merck Silica gel normal-phase (230-240 mesh) and reversed-phase $\mathrm{C}_{18}$ (Merck). Analytical TLC was carried out in silica gel plates (Merck DC-Alufolien $60 \mathrm{~F}_{254}$ ). Compounds were visualized by spraying with $10 \% \mathrm{H}_{2} \mathrm{SO}_{4}$ in $\mathrm{EtOH}$ and heating for 3-5 $\mathrm{min}$.

The high-resolution electrospray ionization mass spectra (HR-ESI-MS) were acquired on a Bruker MicrOTOF-QII spectrometer. The ${ }^{1} \mathrm{H}-\mathrm{NMR}(500 \mathrm{MHz}),{ }^{13} \mathrm{C}-\mathrm{NMR}(125 \mathrm{MHz})$, DEPT, COSY, HSQC, and HMBC spectra were recorded on a Bruker AM500 FT-NMR spectrometer using tetramethylsilane (TMS) as an internal standard.

2.8. Isolation of Pure Compounds. CVSM extract (330 g) was subjected to silica gel column chromatography and eluted with gradient solvent systems of chloroform and methanol (95:5 $\longrightarrow 5: 95, \mathrm{v} / \mathrm{v})$ to collect six fractions: M1 (20 g), M2 (32 g), M3 (90 g), M4 (80 g), M5 (47 g), and M6 (62 g). The fraction M4 (80 g) was chromatographed on silica gel and eluted with $\mathrm{CHCl}_{3}-\mathrm{MeOH}(6: 1 \longrightarrow 3: 1, \mathrm{v} / \mathrm{v})$ to give four subfractions (M4.1-M4.4). The subfraction M4.2 (18g) was separated and further purified by RP-18 with $\mathrm{MeOH}-\mathrm{H}_{2} \mathrm{O}(4$ : $1, \mathrm{v} / \mathrm{v})$ to deliver compounds $1(150 \mathrm{mg}), 3(2 \mathrm{~g})$, and 4 (250 mg). The fraction M5 $(5 \mathrm{~g})$ was applied on a silica gel chromatographic column and eluted with $\mathrm{CHCl}_{3}-\mathrm{MeOH}(2$ : $1, \mathrm{v} / \mathrm{v})$ to yield compound $2(50 \mathrm{mg})$.

Similarly, CCSM extract ( $420 \mathrm{~g}$ ) was subjected to silica gel column chromatography and eluted with $\mathrm{CHCl}_{3}-\mathrm{MeOH}$ $(95: 5-5: 95, \mathrm{v} / \mathrm{v})$ to get seven fractions: M1 (15 g), M2 (25 g), M3 (20 g), M4 (18 g), M5 (15 g), M6 (11 g), and M7 (52 g). The fraction $\mathrm{M} 3(20 \mathrm{~g})$ was eluted with $\mathrm{CHCl}_{3}-\mathrm{MeOH}-\mathrm{H}_{2} \mathrm{O}(5: 1$ : $0.1, \mathrm{v} / \mathrm{v} / \mathrm{v})$ by silica gel column chromatography to receive compound $8(30 \mathrm{mg})$. The fraction M4 $(18 \mathrm{mg})$ was loaded on silica gel column chromatography using $\mathrm{CHCl}_{3}-\mathrm{MeOH}-\mathrm{H}_{2} \mathrm{O}$ $(4: 1: 0.1, \mathrm{v} / \mathrm{v} / \mathrm{v})$ and furnished compound $5(70 \mathrm{mg})$. The fraction M5 (15 g) was separated on a silica gel column with $\mathrm{CHCl}_{3}-\mathrm{MeOH}-\mathrm{H}_{2} \mathrm{O}(3: 1: 0.1, \mathrm{v} / \mathrm{v} / \mathrm{v})$ to obtain compound $6(45 \mathrm{mg})$. The fraction M6 $(11 \mathrm{~g})$ was eluted with $\mathrm{CHCl}_{3}-\mathrm{MeOH}-\mathrm{H}_{2} \mathrm{O}(2: 1: 0.1, \mathrm{v} / \mathrm{v} / \mathrm{v})$ on a silica gel column chromatography to yield compound 7 (18 mg).

\section{Results and Discussion}

3.1. Protective Activity of Extracts against $\mathrm{CCl}_{4}$-Induced Hepatoxicity in HepG2 Cells. The in vitro cytotoxic and hepatoprotective effects of extracts were shown in Tables 1 and 2.

The ethyl acetate extract of $C$. chelidonii stems mostly increased cell viability. Particularly, after $24 \mathrm{~h}$ of treatment, it increased $25 \%$ and $26 \%$ at the concentrations of 50 and $100 \mu \mathrm{g} / \mathrm{mL}$, respectively; after $48 \mathrm{~h}$ of treatment, at $50 \mu \mathrm{g} / \mathrm{mL}$, it increased $25 \%$ and $50 \%$, respectively; after $72 \mathrm{~h}$ of treatment, at $100 \mu \mathrm{g} / \mathrm{mL}$, it increased $26 \%$ and $60 \%$, respectively.

The $n$-hexane and methanol extracts of $C$. chelidonii stems, after $72 \mathrm{~h}$ of treatment, at $100 \mu \mathrm{g} / \mathrm{mL}$, approximately increased $21.4 \%$, while the $n$-hexane and methanol extracts of $C$. chelidonii leaves, after $72 \mathrm{~h}$ of treatment at $100 \mu \mathrm{g} / \mathrm{mL}$, increased $26.9 \%$ and $30 \%$, respectively. Meanwhile, the ethyl acetate and methanol extracts of $C$. viscosa leaves and the $n$ hexane extract of $C$. viscosa stems, after $72 \mathrm{~h}$ treatment, at $100 \mu \mathrm{g} / \mathrm{mL}$, increased from $20 \%$ to $30 \%$ cell viability.

The results show that the methanol extracts of the stems of C. chelidonii and C. viscosa significantly revealed in vitro hepatoprotective activity. Thus, these ones were further examined for in vivo hepatoprotection against $\mathrm{CCl}_{4}$-induced liver toxicity in mice.

3.2. Hepatic Protective Effect of Extracts against CCl4-induced Liver Injury in Mice. The in vivo hepatoprotective effects of methanolic extracts of the stems of $C$. chelidonii and C. viscosa (Table 3 and Figure 1) were tested against $\mathrm{CCl}_{4}$ induced toxicity of liver in mice.

At the doses of $30 \mathrm{mg} / \mathrm{kg}$ and $45 \mathrm{mg} / \mathrm{kg}$, the methanol extracts of the stems of C. chelidonii and C. viscosa (CCSM and CVSM) significantly decreased ALT and AST concentrations in comparison with untreated extracts and the hepatic protection of these extracts was comparable to that of silymarin.

This result warranted the CCSM and CVSM extracts to be further investigated on phytochemical components.

\subsection{Phytochemical Components of the Most Hepatic Protective} Effect Extracts. The most in vitro and in vivo liver protection extracts of two species stems (CCSM and CVSM) were subjected to silica gel normal-phase and reversed-phase RP18 chromatography to give eight known flavonoids (1-8) whose structures were confirmed by HR-ESI-MS, NMR experiments, and comparisons with the published data: visconoside A (1), visconoside B (2) [20], quercetin 3-O$\beta$-D-glucopyranoside $\quad 7$-O- $\alpha$-L-rhamnopyranoside (3), kaempferol 3-O- $\beta$-D-glucopyranoside $7-O-\alpha$-L-rhamnopyranoside (4) [18], cleomeside A (5), cleomeside B (6) [19], 
TABLE 1: The cytotoxicity using HepG2 of extracts of Cleome chelidonii.

\begin{tabular}{|c|c|c|c|c|c|c|c|c|c|}
\hline \multirow[b]{2}{*}{ Concentration $(\mu \mathrm{g} / \mathrm{mL})$} & \multirow[b]{2}{*}{$\mathrm{CCSH}$} & \multirow[b]{2}{*}{ Control } & \multicolumn{2}{|c|}{$\mathrm{OD}_{570} \pm \mathrm{SEM}$} & \multirow[b]{2}{*}{ CCSM } & \multirow[b]{2}{*}{ Control } & \multicolumn{3}{|c|}{$\begin{array}{c}\text { Percentage of control } \\
\text { (\%) }\end{array}$} \\
\hline & & & CCSE & Control & & & $\mathrm{CCSH}$ & CCSE & CCSM \\
\hline \multicolumn{10}{|l|}{ After $24 \mathrm{~h}$ of treatment } \\
\hline 100 & $0.281 \pm 0.010$ & $0.243 \pm 0.002$ & $0.269 \pm 0.002$ & $0.213 \pm 0.003$ & $0.293 \pm 0.009$ & \multirow{4}{*}{$0.313 \pm 0.012$} & 108.3 & 126.4 & 93.7 \\
\hline 50 & $0.281 \pm 0.008$ & $0.260 \pm 0.006$ & $0.266 \pm 0.004$ & $0.216 \pm 0.007$ & $0.300 \pm 0.010$ & & 107.0 & 123.6 & 95.9 \\
\hline 25 & $0.270 \pm 0.007$ & \multirow{2}{*}{$0.263 \pm 0.008$} & $0.250 \pm 0.005$ & \multirow{2}{*}{$0.231 \pm 0.007$} & $0.281 \pm 0.010$ & & 102.7 & 108.1 & 90.0 \\
\hline DOX 10 & $0.149 \pm 0.005$ & & $0.149 \pm 0.005$ & & $0.164 \pm 0.006$ & & 56.7 & 59.3 & 52.5 \\
\hline \multicolumn{10}{|l|}{ After $48 \mathrm{~h}$ of treatment } \\
\hline 100 & $0.402 \pm 0.010$ & $0.282 \pm 0.005$ & $0.420 \pm 0.003$ & $0.265 \pm 0.009$ & $0.313 \pm 0.007$ & \multirow{4}{*}{$0.326 \pm 0.005$} & 117.8 & 158.4 & 95.9 \\
\hline 50 & $0.367 \pm 0.004$ & $0.341 \pm 0.011$ & $0.396 \pm 0.006$ & $0.319 \pm 0.004$ & $0.323 \pm 0.010$ & & 97.1 & 124.3 & 98.9 \\
\hline 25 & $0.367 \pm 0.005$ & \multirow{2}{*}{$0.378 \pm 0.011$} & $0.360 \pm 0.007$ & \multirow{2}{*}{$0.359 \pm 0.005$} & $0.314 \pm 0.007$ & & 97.2 & 100.3 & 96.3 \\
\hline DOX 10 & $0.113 \pm 0.004$ & & $0.112 \pm 0.003$ & & $0.091 \pm 0.002$ & & 29.9 & 31.2 & 27.9 \\
\hline \multicolumn{10}{|l|}{ After $72 \mathrm{~h}$ of treatment } \\
\hline 100 & $0.429 \pm 0.012$ & $0.315 \pm 0.010$ & $0.441 \pm 0.014$ & $0.289 \pm 0.012$ & $0.403 \pm 0.014$ & \multirow{4}{*}{$0.339 \pm 0.022$} & 121.4 & 152.2 & 118.6 \\
\hline 50 & $0.394 \pm 0.016$ & $0.353 \pm 0.009$ & $0.420 \pm 0.012$ & $0.329 \pm 0.009$ & $0.410 \pm 0.017$ & & 98.7 & 127.6 & 120.8 \\
\hline 25 & $0.388 \pm 0.011$ & \multirow{2}{*}{$0.399 \pm 0.006$} & $0.441 \pm 0.017$ & \multirow{2}{*}{$0.393 \pm 0.006$} & $0.406 \pm 0.010$ & & 97.3 & 112.3 & 119.5 \\
\hline DOX 10 & $0.071 \pm 0.002$ & & $0.076 \pm 0.001$ & & $0.068 \pm 0.001$ & & 17.8 & 19.3 & 20.0 \\
\hline
\end{tabular}

TABle 2: The cytotoxicity using HepG2 of extracts of Cleome viscosa.

\begin{tabular}{|c|c|c|c|c|c|c|c|c|c|}
\hline \multirow[b]{2}{*}{ Concentration $(\mu \mathrm{g} / \mathrm{mL})$} & \multirow[b]{2}{*}{$\mathrm{CVSH}$} & \multirow[b]{2}{*}{ Control } & \multicolumn{2}{|c|}{$\mathrm{OD}_{570} \pm \mathrm{SEM}$} & \multirow[b]{2}{*}{ CVSM } & \multirow[b]{2}{*}{ Control } & \multicolumn{3}{|c|}{$\begin{array}{c}\text { Percentage of control } \\
(\%)\end{array}$} \\
\hline & & & CVSE & Control & & & $\mathrm{CVSH}$ & CVSE & CVSM \\
\hline \multicolumn{10}{|l|}{ After $24 \mathrm{~h}$ of treatment } \\
\hline 100 & $0.232 \pm 0.014$ & $0.234 \pm 0.004$ & $0.274 \pm 0.009$ & $0.244 \pm 0.009$ & $0.267 \pm 0.008$ & \multirow{4}{*}{$0.230 \pm 0.007$} & 92.9 & 112.2 & 116.3 \\
\hline 50 & $0.254 \pm 0.008$ & $0.250 \pm 0.008$ & $0.256 \pm 0.007$ & $0.242 \pm 0.005$ & $0.265 \pm 0.011$ & & 98.0 & 105.7 & 115.5 \\
\hline 25 & $0.260 \pm 0.004$ & \multirow{2}{*}{$0.259 \pm 0.012$} & $0.258 \pm 0.010$ & \multirow{2}{*}{$0.266 \pm 0.004$} & $0.250 \pm 0.013$ & & 100.3 & 96.7 & 108.7 \\
\hline DOX 10 & $0.157 \pm 0.004$ & & $0.186 \pm 0.006$ & & $0.164 \pm 0.006$ & & 60.5 & 69.8 & 51.7 \\
\hline \multicolumn{10}{|l|}{ After $48 \mathrm{~h}$ of treatment } \\
\hline 100 & $0.314 \pm 0.009$ & $0.268 \pm 0.008$ & $0.274 \pm 0.009$ & $0.271 \pm 0.012$ & $0.322 \pm 0.008$ & \multirow{4}{*}{$0.312 \pm 0.007$} & 97.2 & 101.4 & 103.4 \\
\hline 50 & $0.308 \pm 0.011$ & $0.306 \pm 0.011$ & $0.304 \pm 0.009$ & $0.291 \pm 0.008$ & $0.311 \pm 0.002$ & & 85.4 & 104.6 & 99.8 \\
\hline 25 & $0.329 \pm 0.008$ & \multirow{2}{*}{$0.365 \pm 0.003$} & $0.297 \pm 0.008$ & \multirow{2}{*}{$0.332 \pm 0.004$} & $0.311 \pm 0.005$ & & 91.0 & 89.4 & 99.8 \\
\hline DOX 10 & $0.129 \pm 0.003$ & & $0.130 \pm 0.006$ & & $0.114 \pm 0.003$ & & 35.7 & 39.3 & 36.4 \\
\hline \multicolumn{10}{|l|}{ After $72 \mathrm{~h}$ of treatment } \\
\hline 100 & $0.405 \pm 0.014$ & $0.299 \pm 0.019$ & $0.279 \pm 0.013$ & $0.303 \pm 0.014$ & $0.365 \pm 0.007$ & \multirow{4}{*}{$0.325 \pm 0.008$} & 121.7 & 92.2 & 112.3 \\
\hline 50 & $0.368 \pm 0.005$ & $0.333 \pm 0.011$ & $0.374 \pm 0.028$ & $0.345 \pm 0.012$ & $0.372 \pm 0.013$ & & 97.2 & 108.3 & 114.5 \\
\hline 25 & $0.368 \pm 0.015$ & \multirow{2}{*}{$0.378 \pm 0.008$} & $0.356 \pm 0.020$ & \multirow{2}{*}{$0.390 \pm 0.017$} & $0.381 \pm 0.014$ & & 97.3 & 91.4 & 117.2 \\
\hline DOX 10 & $0.073 \pm 0.002$ & & $0.075 \pm 0.001$ & & $0.066 \pm 0.001$ & & 19.2 & 19.3 & 20.3 \\
\hline
\end{tabular}

TABLE 3: The hepatoprotection of the methanol extracts of the stems of C. viscosa and C. chelidonii against $\mathrm{CCl}_{4}$-induced toxicity of liver in mice.

\begin{tabular}{lcccc}
\hline \multirow{2}{*}{ Group } & \multicolumn{2}{c}{ CVSM extract } & \multicolumn{2}{c}{ CCSM extract } \\
& ALT & AST & ALT & AST \\
\hline I (normal control) & $22.50 \pm 7.42$ & $21.75 \pm 6.34$ & $30.50 \pm 10.15$ & $72.75 \pm 13.60$ \\
II (CCl -intoxicated) & $188.75 \pm 81.81$ & $233.00 \pm 71.36$ & $508.50 \pm 113.09$ & $470.50 \pm 112.34$ \\
III (positive group) & $29.00 \pm 11.40$ & $23.50 \pm 9.15$ & $26.75 \pm 19.52$ & $23.50 \pm 12.34$ \\
IV (test group, $15 \mathrm{mg} / \mathrm{kg})$ & $66.25 \pm 72.91$ & $54.50 \pm 46.92$ & $41.75 \pm 23.37$ & $38.75 \pm 2.06$ \\
V (test group, $30 \mathrm{mg} / \mathrm{kg}$ ) & $53.00 \pm 25.22$ & $58.00 \pm 32.79$ & $37.00 \pm 34.30$ & $24.50 \pm 16.26$ \\
VI (test group, $45 \mathrm{mg} / \mathrm{kg}$ ) & $83.75 \pm 72.54$ & $78.00 \pm 59.70$ & $20.25 \pm 9.07$ & $21.00 \pm 9.13$ \\
\hline
\end{tabular}

cleomeside $\mathrm{C}(7)$, and quercetin-3-O-[ $\beta$-D-glucopyr-

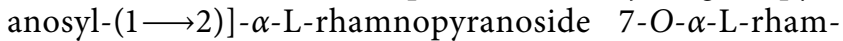
nopyranoside (8) [17] (Figure 2).

The phytochemical study confirmed that flavonoids are the main components of two species, which might be representative of their hepatoprotective effect. Therefore, the hepatoprotections of flavonoids (1-8) were screened using HepG2 cell line.

3.4. Cytotoxicity and Hepatoprotective Activity of Purified Compounds. The cytotoxicity (Table 4) and hepatoprotection 


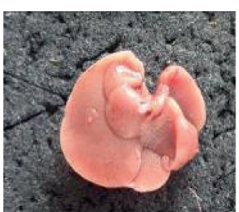

I

(normal control)

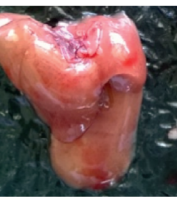

I

(normal control)

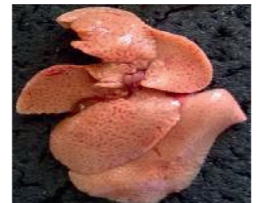

II

( $\mathrm{CCl}_{4}$-intoxicated)

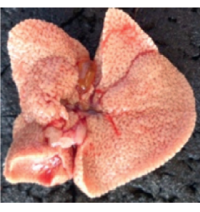

$\left(\mathrm{CCl}_{4}\right.$-intoxicated $)$

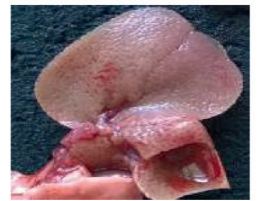

III

(positive group)

(a)

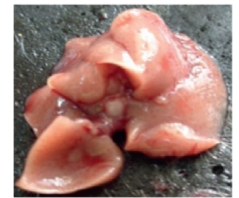

III

(positive group)

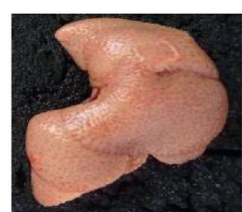

IV

(test group, $15 \mathrm{mg} / \mathrm{kg}$ )

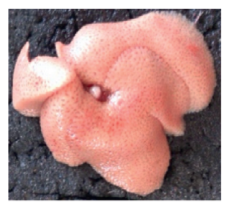

IV

(test group, $15 \mathrm{mg} / \mathrm{kg}$ )

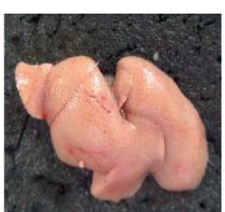

V

(test group,

$30 \mathrm{mg} / \mathrm{kg}$ )

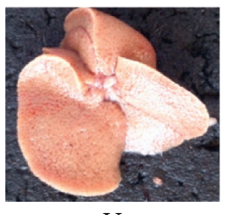

$\mathrm{V}$

(test group, $30 \mathrm{mg} / \mathrm{kg}$ )

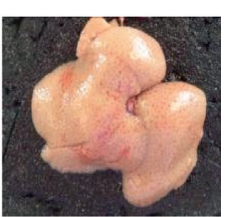

VI

(test group, $45 \mathrm{mg} / \mathrm{kg}$ )

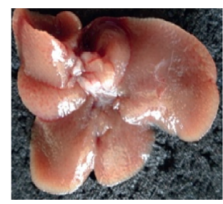

VI

(test group, $45 \mathrm{mg} / \mathrm{kg}$ )

(b)

Figure 1: Photographs of livers from normal and treated mice. (a) The methanol extract of the stems of C. viscosa (CVSM). (b) The methanol extract of the stems of C. chelidonii (CCSM).<smiles>[R16]c1cc(O)c2c(=O)c(OC(C)(C)C)c(-c3ccc(O)c(Br)c3)oc2c1</smiles>

\begin{tabular}{|c|c|c|c|c|}
\hline Compound & $\mathrm{R}_{1}$ & $\mathrm{R}_{2}$ & $\mathrm{R}_{3}$ & $\mathrm{R}_{4}$ \\
\hline 1 & $\mathrm{OH}$ & $\mathrm{OH}$ & Glc- $(1 \rightarrow 3)-4-O A c-R h a$ & Rha \\
\hline 2 & $\mathrm{OH}$ & $\mathrm{OH}$ & [Sinapinoyl- $(1 \rightarrow 6)]$-Glc- $(1 \rightarrow 3)-4$-OAc-Rha & Rha \\
\hline 3 & $\mathrm{OH}$ & $\mathrm{OH}$ & Glc & Rha \\
\hline 4 & $\mathrm{H}$ & $\mathrm{OH}$ & Glc & Rha \\
\hline 5 & $\mathrm{OH}$ & $\mathrm{OH}$ & Glc- $(1 \rightarrow 2)-$ Rha & 4-OAc-Rha \\
\hline 6 & $\mathrm{OH}$ & $\mathrm{OH}$ & [Coumaroyl- $(1 \rightarrow 6)]$-Glc- $(1 \rightarrow 2)-$ Rha & 4-OAc-Rha \\
\hline 7 & $\mathrm{H}$ & $\mathrm{OH}$ & {$[(6$-Feruloyl)-( $1 \rightarrow 2)$-Glc; (6-Coumaroyl)-( $1 \rightarrow 3)$-Glc]-Rha } & Rha \\
\hline 8 & $\mathrm{OH}$ & $\mathrm{OH}$ & Glc- $(1 \rightarrow 2)-$ Rha & Rha \\
\hline
\end{tabular}

Figure 2: Structure of isolated flavonoids 1-8.

TABLE 4: The cytotoxicity using HepG2 of isolated compounds 1-8.

\begin{tabular}{lcccc}
\hline Sample & Concentration $(\mu \mathrm{M})$ & OD $_{570} \pm$ SEM & Control & Percentage of control (\%) \\
\hline Quercetin & 10 & $0.183 \pm 0.004$ & $0.191 \pm 0.003$ & 95.8 \\
1 & 100 & $0.151 \pm 0.007$ & $0.161 \pm 0.003$ & 94.1 \\
& 50 & $0.169 \pm 0.008$ & $0.177 \pm 0.010$ & 95.3 \\
25 & 25 & $0.157 \pm 0.003$ & $0.194 \pm 0.010$ & 109.1 \\
& 100 & $0.175 \pm 0.004$ & $0.161 \pm 0.003$ & 94.1 \\
3 & 50 & $0.167 \pm 0.005$ & $0.177 \pm 0.010$ & 97.0 \\
& 25 & $0.188 \pm 0.005$ & $0.194 \pm 0.010$ & 116.4 \\
& 100 & $0.187 \pm 0.012$ & $0.161 \pm 0.003$ & 98.1 \\
\end{tabular}


TABle 4: Continued.

\begin{tabular}{|c|c|c|c|c|}
\hline Sample & Concentration $(\mu \mathrm{M})$ & $\mathrm{OD}_{570} \pm \mathrm{SEM}$ & Control & Percentage of control (\%) \\
\hline \multirow{3}{*}{4} & 100 & $0.167 \pm 0.012$ & $0.161 \pm 0.003$ & 103.6 \\
\hline & 50 & $0.166 \pm 0.008$ & $0.177 \pm 0.010$ & 93.8 \\
\hline & 25 & $0.164 \pm 0.006$ & $0.194 \pm 0.010$ & 84.8 \\
\hline \multirow{3}{*}{5} & 100 & $0.169 \pm 0.172$ & $0.161 \pm 0.003$ & 68.2 \\
\hline & 50 & $0.147 \pm 0.139$ & $0.177 \pm 0.010$ & 78.6 \\
\hline & 25 & $0.140 \pm 0.132$ & $0.194 \pm 0.010$ & 68.2 \\
\hline \multirow{3}{*}{6} & 100 & $0.165 \pm 0.010$ & $0.161 \pm 0.003$ & 102.7 \\
\hline & 50 & $0.162 \pm 0.008$ & $0.177 \pm 0.010$ & 91.6 \\
\hline & 25 & $0.152 \pm 0.008$ & $0.194 \pm 0.010$ & 78.3 \\
\hline \multirow{3}{*}{7} & 100 & $0.143 \pm 0.006$ & $0.161 \pm 0.003$ & 89.0 \\
\hline & 50 & $0.153 \pm 0.018$ & $0.177 \pm 0.010$ & 86.3 \\
\hline & 25 & $0.406 \pm 0.018$ & $0.194 \pm 0.010$ & 209.8 \\
\hline \multirow{3}{*}{8} & 100 & $0.188 \pm 0.010$ & $0.161 \pm 0.003$ & 116.7 \\
\hline & 50 & $0.140 \pm 0.003$ & $0.177 \pm 0.010$ & 78.8 \\
\hline & 25 & $0.149 \pm 0.009$ & $0.194 \pm 0.010$ & 77.0 \\
\hline
\end{tabular}

TABLE 5: The hepatoprotective activities using HepG2 of all isolated compounds 1-8 at a concentration of $100 \mu \mathrm{M}$.

\begin{tabular}{lccc}
\hline \multirow{2}{*}{ Sample } & \multicolumn{2}{c}{$\mathrm{OD}_{570} \mathrm{~nm} \pm \mathrm{SEM}$} & Prevention percentage (\%) \\
\hline Control & $\mathrm{CCl}_{4} 2 \mathrm{mM}(-)$ & $\mathrm{CCl}_{4} 2 \mathrm{mM}(+)$ & - \\
Control DMSO 1\% & $0.191 \pm 0.003$ & $0.157 \pm 0.010$ & $6.119 \pm 0.004$ \\
1 & $0.161 \pm 0.003$ & $0.147 \pm 0.004$ & 64.1 \\
2 & $0.151 \pm 0.007$ & $0.146 \pm 0.006$ & -33.5 \\
3 & $0.175 \pm 0.004$ & $0.106 \pm 0.005$ & 74.2 \\
4 & $0.187 \pm 0.012$ & $0.150 \pm 0.006$ & 13.3 \\
5 & $0.167 \pm 0.012$ & $0.125 \pm 0.005$ & 32.3 \\
6 & $0.172 \pm 0.009$ & $0.133 \pm 0.003$ & -34.7 \\
7 & $0.165 \pm 0.010$ & $0.105 \pm 0.008$ & 14.1 \\
8 & $0.143 \pm 0.006$ & $0.125 \pm 0.009$ & 80.3 \\
\hline
\end{tabular}

(Table 5) using HepG2 cell line of all separated compounds 1-8 were measured by MTT assay.

At tested concentrations, samples did not show cytotoxicity, except compounds 3, 5, 6, and 8 at $25 \mu \mathrm{M}$ (cell viability decreased, ranging from $25.0 \%$ to $30.0 \%$ ).

At the concentration of $100 \mu \mathrm{M}$, compounds 1 and 4 significantly showed hepatoprotective effect (with prevention percentages of $66.5 \%$ and $74.2 \%$, respectively), whereas compounds 5 and 8 disclosed weaker activity (with prevention percentages of $32.3 \%$ and $34.3 \%$, respectively, compared to that of $80.3 \%$ of quercetin positive control).

The hepatoprotective effects of compounds 1 and 4 were tested for the first time.

\section{Conclusions}

In vitro and in vivo hepatoprotections using HepG2 and in mice of $C$. chelidonii and C. viscosa stems and their phytochemical constituents were investigated for the first time. The phytochemical study evidenced that flavonoids are the main compounds of two species. Furthermore, the hepatoprotections of visconoside $\mathrm{A}(1)$ and kaempferol 3-O$\beta$-D-glucopyranoside $7-O-\alpha$-L-rhamnopyranoside (4) were identified for the first time. However, further clinical examinations are required to determine the molecular mechanisms of hepatoprotection as well as qualitative and quantitative identification of main biological flavonoid markers (1, 4, and 6) from these species.

The present study suggests that C. chelidonii and C. viscosa plants are good sources of natural hepatoprotective agents and contribute to understanding the biological activities of Cleome species in traditional Vietnamese medicine.

\section{Data Availability}

All the data related to the study are available from the corresponding author and can be provided upon request.

\section{Conflicts of Interest}

The authors declare that there are no conflicts of interest regarding the publication of this paper.

\section{Acknowledgments}

This work was partially supported by the Vietnam Academy of Science and Technology, Project no. UDSXTN.03/19-20, and Binh Phu Pharma Ltd. 


\section{References}

[1] W. Abdullah, W. M. Elsayed, K. A. Abdelshafeek et al., "Chemical constituents and biological activities of Cleome genus: a brief review," International Journal of Pharmacognosy and Phytochemical Research, vol. 8, no. 5, pp. 777-787, 2016.

[2] V. V. Chi and T. Hop, Cây cỏ có ích [Vietnam Useful Plants], Vietnam Education Publishing House, Hanoi, Vietnam, 2002.

[3] S. Parimalakrishnan, A. Dey, A. Smith, and R. Manavalan, "Evaluation of anti-inflammatory, antinociceptive and antipyretic effects of methanolic extract of Cleome chelidoniii," International Journal of Biological and Chemical Sciences, vol. 1, no. 3, pp. 223-228, 2007.

[4] Y. Trilochana, D. J. M. Babu, and P. R. Rao, "The study of antihyperglycaemic activity of aqueous extract of root of Cleome chelidonii herb in rats," Indian Journal of Research in Pharmacy and Biotechnology, vol. 5, no. 2, pp. 88-93, 2017.

[5] N. VijayaRekha, S. K. Godasu, G. S. V. D. Jyothi, and K. Hemanth, "Phytochemical and pharmacological activities of Polygala chainensis, Cleome chelidonii," International Journal of Pharmacognosy, vol. 6, no. 7, pp. 253-258, 2019.

[6] A. Mishra, A. K. Mishra, and S. K. Jain, "Anticonvulsant activity of Cleome viscosa seed extracts in swiss albino mice," International Journal of Pharmacognosy and Pharmaceutical Sciences, vol. 2, no. 1, pp. 177-181, 2010.

[7] V. Y. Gopal, A. Ravindernath, and G. Kalpana, P. V. Reddy, Antitumor activity of Cleome viscosa against ehrlich ascites carcinoma (EAC) in swiss albino mice," International Journal of Phytopharmacy, vol. 2, no. 2, pp. 51-55, 2012.

[8] A. P. Jayaprakash, K. R. Krishnakumar, K. K. Srinivasan et al., "Evaluation of antioxidant, cytotoxic and anticancer effects of Cleome viscosa Linn," European Journal of Pharmaceutical and Medical Research, vol. 3, no. 4, pp. 253-262, 2016.

[9] S. Sriwatcharakul, "Antimicrobial, antioxidant and cytotoxic activities of Cleoma viscosa Linn. crude extracts," International Journal of Bioengineering and Life Sciences, vol. 10, no. 7, pp. 435-438, 2016.

[10] U. Bose, V. Bala, T. N. Ghosh, K. Gunasekaran, and A. A. Rahman, "Antinociceptive, cytotoxic and antibacterial activities of Cleome viscosa leaves," Revista Brasileira de Farmacognosia, vol. 21, no. 1, pp. 165-169, 2011.

[11] S. A. Rimi, S. Hossain, S. Islam, Z. Islam, S. B. Chhabi, and N. Islam, "Bioactive potentials of Cleome viscosa L. extracts: dose-mortality, insect repellency and brine shrimp lethality," Journal of Scientific Research, vol. 9, no. 4, pp. 375-382, 2017.

[12] S. S. Kamble and R. N. Gacche, "Evaluation of anti-breast cancer, anti-angiogenic and antioxidant properties of selected medicinal plants," European Journal of Integrative Medicine, vol. 25, pp. 13-19, 2019.

[13] T. O. Elufioye and J. O. Onoja, "In vivo anti-malarial activity of Cleome viscosa L. whole plant," Research Journal of Phytochemistry, vol. 10, no. 1, pp. 30-38, 2016.

[14] Egbuji and I. Walter, "Evaluation of the larvicidal activity of acetone extract of Cleome viscosa pod on the larvae of female anopheles gambiae," IDOSR International Digital Organization for Scientific Research, vol. 5, no. 1, pp. 27-43, 2020.

[15] S. Singh, S. Singh, D. Tripathi et al., "Evaluation of Cleome viscosa L. roots extract (s): anti-allergic, antioxidant and diuretic activities in association of phenolic profile," European Journal of Molecular \& Clinical Medicine, vol. 7, no. 10, pp. 3496-3511, 2021.

[16] C. O. Opara and K. Usman, "Evaluation of the analgesic and antipyretic properties of African Cleome viscosa,"
International Journal of Basic \& Clinical Pharmacology, vol. 7, no. 7, pp. 1220-1225, 2018.

[17] Y. Suresh, G. Rajasekar, T. Lavanya et al., "Antioxidant and antidiabetic properties of isolated fractions from methanolic extract derived from the whole plant of Cleome viscosa L." Future Journal of Pharmaceutical Sciences, vol. 6, no. 103, 2020.

[18] R. Pragadheeswari and K. Sangeetha, "Diabetic foot wound care treatment using Cleome viscosa herb," in Proceedings of the 2016 International Conference on Information Engineering, Management and Security, pp. 107-110, Kuala Lumpur, Malaysia, 2016.

[19] A. M. Donkor, K. G. Bugri, and E. A. Atindaana, "Evaluation of antibacterial potentiation of crude extracts of Phyllanthus amarus, Tamarindus indica and Cleome viscosa and their formulation," International Journal of Plant Research, vol. 4, no. 1, pp. 23-28, 2014.

[20] N. Sridhar, B. V. V. S. S. Kiran, D. T. Sasidhar, and L. K. Kanthal, "In vitro antimicrobial screening of methanolic extracts of Cleome chelidonii and Cleome gynandra," Bangladesh Journal of Pharmacology, vol. 9, no. 2, pp. 161-166, 2014.

[21] A.-M. Donkor, D. Oduro-Mens, and M. K.-A. Patience, "In vitro antibacterial activity of PEG formulations of crude extracts of Cleome viscosa, Tamarindus indica and Euphorbia hirta," Research Journal of Microbiology, vol. 11, no. 6, pp. 202-207, 2016.

[22] H. Sheeba, M. Syed Ali, and V. Anuradha, "Bioactive compounds and antimicrobial activity of fungal crude extract from medicinal plants," Journal of Pharmaceutical Sciences and Research, vol. 11, no. 5, pp. 1826-1833, 2019.

[23] M. D. C. Juárez-Vázquez, M. A. Jiménez-Arellanes, and M. A. Jiménez-Arellanes, "Phytochemical investigation, anti-inflammatory and antinociceptive activities from some species of Cleomaceae family: a systematic review," $A d$ vancement in Medicinal Plant Research, vol. 7, no. 4, pp. 107-128, 2019.

[24] M. M. Begum and K. R. Kiran, "Evaluation of methanolic extract of Cleome chelidonii for hepatoprotective activity against paracetamol and ethanol induced hepatotoxicity in rats," International Journal of Pharmaceutical Sciences Review and Research, vol. 5, no. 1, pp. 28-36, 2016.

[25] P.-D. Nguyen, C. Sayagh, N. Borie, and C. Lavaud, "Antiradical flavonol glycosides from the aerial parts of Cleome chelidonii L.f," Phytochemistry, vol. 142, pp. 30-37, 2017.

[26] P. C. Gupta, N. Sharma, and C. V. Rao, "Comparison of the antioxidant activity and total phenolic, flavonoid content of aerial part of Cleome viscosa L." International Journal of Phytomedicine, vol. 3, pp. 386-391, 2011.

[27] T. Elufioye and J. Onoja, "Anti-oxidant capacity and phenolic content of methanolic extract of Cleome viscosa L. Whole plant and its derived fractions," European Journal of Medicinal Plants, vol. 11, no. 1, pp. 1-9, 2016.

[28] S. Ethadi, R. Pragada, and G. Battu, "Evaluation of anti-inflammatory and hepatoprotective activities of different extracts of Cleome chelidonii root in albino rats," International Journal of Pharma and Bio Sciences, vol. 4, no. 4, pp. 111-119, 2013.

[29] S. V. Kumar, A. J. M. Christina, P. V. GeethaRani, G. Nalini, and N. Chidambaranathan, "Antifibrotic effect of Cleome viscosa Linn on Carbon tetra chloride $\left(\mathrm{CCl}_{4}\right)$ induced liver fibrosis," Der Pharma Chemica, vol. 13, no. 1, pp. 92-96, 2009.

[30] B. L. Narsimhulu, Y. Suresh, G. Rajasekar et al., "Evaluation of hepatoprotective and nephroprotective activity of methanolic 
extract of Cleome viscosa and Cleome gynandra in STZ-induced diabetic rats," The Pharma Innovation Journal, vol. 8, no. 2, pp. 574-581, 2019.

[31] N. K. Gupta and V. K. Dixit, "Evaluation of hepatoprotective activity of Cleome viscosa Linn. extract," Indian Journal of Pharmacology, vol. 41, no. 1, pp. 36-40, 2009.

[32] N. K. Gupta and V. K. Dixit, "Hepatoprotective activity of Cleome viscosa Linn. extract against thioacetamide-induced hepatotoxicity in rats," Natural Product Research, vol. 23, no. 14, pp. 1289-1297, 2009.

[33] A. K. Mobiya, A. Patidar, K. Patidar et al., "Hepatoprotective effect of Cleome viscosa L. seeds in paracetamol induced hepatotoxic rats," International Journal of Pharmaceutical and Biological Science Archive, vol. 1, no. 4, pp. 399-403, 2010.

[34] R. Rajaraman, R. Saravanan, B. Dheeba, and S. Ramalingam, "In vivo investigation of hepatoprotective activity of Cleome viscosa L. in albino rats," Der Pharmacia Lettre, vol. 8, no. 3, pp. 308-313, 2016.

[35] T. P. Nguyen, N. P. Minh, T. B. Dat et al., "Limonoid from the rhizomes of luvunga scandens (roxb.) buch. Ham," Natural Product Research, vol. 31, no. 19, pp. 2281-2285, 2017.

[36] T. P. Nguyen, D. T. Mai, T. H. T. Do, and N. M. Phan, "Flavonoids with hepatoprotective activity from the leaves of Cleome chelidonii," Natural Product Communications, vol. 12, no. 7, pp. 1061-1063, 2017.

[37] T. P. Nguyen, C. L. Tran, C. H. Vuong et al., "Flavonoids with hepatoprotective activity from the leaves of Cleome viscosa L," Natural Product Research, vol. 31, no. 22, pp. 2587-2592, 2017.

[38] N. M. Phan, D. T. Mai, T. P. Nguyen et al., "Two new flavonol glycosides from the leaves of Cleome chelidonii L.f," Journal of Asian Natural Products Research, vol. 17, no. 4, pp. 338-342, 2015.

[39] N. M. Phan, T. P. Nguyen, T. D. Le, T. C. Mai, M. T. Phong, and D. T. Mai, "Two new flavonol glycosides from the leaves of Cleome viscosa L," Phytochemistry Letters, vol. 18, pp. 10-13, 2016. 